\title{
Catastrophe and Caregiving: The Failure of Medicine as an Art
}

\section{Citation}

Kleinman, Arthur. 2008. Catastrophe and caregiving: the failure of medicine as an art. The Lancet 371(9606): 22-23.

\section{Published Version}

http://dx.doi.org/10.1016/S0140-6736(08)60057-4

\section{Permanent link}

http://nrs.harvard.edu/urn-3:HUL.InstRepos:2757543

\section{Terms of Use}

This article was downloaded from Harvard University's DASH repository, and is made available under the terms and conditions applicable to Other Posted Material, as set forth at http:// nrs.harvard.edu/urn-3:HUL.InstRepos:dash.current.terms-of-use\#LAA

\section{Share Your Story}

The Harvard community has made this article openly available.

Please share how this access benefits you. Submit a story.

\section{Accessibility}


Arthur Kleinman.

Harvard University

Department of Anthropology

Catastrophe and Caregiving: the Failure of Medicine as an Art and the Challenge for Medical Humanities

Introduction

In 1966 as a visiting medical student at a celebrated London teaching hospital, I interviewed a young husband and wife who had recently experienced a truly calamitous health catastrophe. In their early $20 \mathrm{~s}$, both virgins, on their wedding night, in their first experience of sexual intercourse, the husband blew out an A-V malformation and was left with a disabling hemiparesis. Stunned, guilt-ridden, and in despair, the couple clutched hands tightly and cried silently as they shared their suffering with me. My job was to get the neurological exam right and diagnose where the rupture had taken place. I remember the famous professor, who went over my findings, repeating the neurological exam and putting me through my paces as a budding diagnostician. He never once alluded to the personal tragedy and the terrible consequences for the sad lovers and the shock to their parents. Finally, I found the courage to tell him that I thought the failure to address what really mattered to them -- -- how to live their lives together from here on -- -- was unacceptable. Surely, it was our medical responsibility to offer them some kind of caregiving, some kind of hope for the future. He smiled at me in a surprised and patronizing way; then he said I was right to insist that there was more to this case than the neurological findings. The professor had the patient and his wife brought back to the lecture hall, where he presided over the teaching rounds, and he gave them as sensitive an interview as I might have hoped for, including empathic suggestions for rehabilitation, family counseling, and social work assistance.

I have long regarded this experience as iconic of contemporary medicine's caregiving paradox. The balance between science/technology and art has shifted so far towards the former that the latter is a pale shadow, a fragile remnant of what had for centuries been crucial to the work of the doctor. That work can be reasserted when we have the time and desire to do so, as the distinguished neurologist showed me, but it is regularly overlooked and left aside.

I am writing this essay after having just visited a noted East Asian Hospital where the doctor-patient relationship for patients returning for follow-up visits is estimated to last between one and three minutes -- -- hardly time to ask a few questions, do the 
quickest physical exam and write a prescription. Not a place where the art of caregiving is likely to flourish. The residents with whom I spoke got the message. The structure of training and of service delivery discourages and even disables the art.

My own personal experience of being the primary caregiver for my wife, on account of her neurodegenerative disorder, convinces me yet further that caregiving has much less to do with doctoring and doctors than the general public realizes or than medical educators are willing to acknowledge. Caregiving is about skilled nursing, competent social work, rehabilitation efforts of physical and occupational therapists, the hard physical work of home health care aides. Yet, for all the efforts of the helping professions, caregiving is for the most part the preserve of families and intimate friends, and of the afflicted person herself/himself.

Like the tragic young partners, whose calamity I limned, victims of health catastrophes and disabling accidents, those suffering serious chronic illnesses, and nearly all of us who come to end-of-life conditions receive little of our caregiving from doctors. We struggle with family and close friends to find practical assistance with the activities of daily living, financial aid, legal and religious advice, emotional support, meaningmaking and remaking, and moral solidarity. About these caregiving activities, we know surprisingly little, other than that they come to define the quality of living for millions of sufferers.

A great 20th-century physician, Walsh McDermott, once proposed, perhaps tongue-in-cheek, that the art of medicine might be split off from the technical scientific skills of diagnosis and treatment, so that physicians could concentrate on what they are good at, and avoid being drawn into the existential practices best left to priests and laypersons. This is a logical option, but one that few medical educators are likely to endorse, and for good reason. The art and science of medicine don't peel off from each other in clean and intact wholes. Taking the patient's history is as much art as science; treatment is pastoral care as well as pharmacological rationality. Prognosis has as much to do with social science data and humanistic interpretation of lives in their social contexts as with the understanding of underlying pathophysiology and pharmacology. The doctor's experience of the world is as important to her caregiving as evidence is to her technical decision-making. No; medicine can't get away from the confounding art of caregiving, even if the medical profession is not its major source. Indeed, the argument can be made that what physicians and medical educators really need to do is to be more critically concerned with the details of caregiving, with its experience in everyday practice, and with obstacles that inhibit physicians' and others' caregiving. But where does the knowledge and skill required for caregiving, and to critically reflect on what obstructs doctors from practicing it, come from? Here, while nursing and social work have important things to contribute, the humanities and interpretive social sciences really do matter for doctors, and perhaps for all the other caregivers too.

\section{Caregiving, Moral Experience, and Ethical Aspiration.}


Caregiving is configured by economists as "burden", by psychologists as "coping", by health services researchers in terms of social resources and health care costs, and by physicians as a clinical skill. Each of these perspectives represents part of the picture. For the medical humanities and interpretive social sciences, caregiving is a foundational component of moral experience. By this I mean that caregiving is envisioned as an existential quality of what it is to be human. We give care (and receive it) as part of the flow of every day (and extraordinary) lived values and emotions that make up moral experience. Here collective values and social emotions are as influential as individual ones. Within these local moral worlds -- -- family, network, institution, community -- -- caregiving is one of those things that really matters, but usually not the only thing. Contestation over what matters most as well as perceived (and all-too-real) threats (financial, cultural, personal) to those lived values figure importantly in how care is organized, provided, received, and evaluated. Interpretive perspectives on the process of giving and receiving care lead medical humanists to reflect on local patterns of moral life that give rise to criticism of interference (structural and idiosyncratic) with caregiving, resistance to major local forces that cause such interference, and perhaps most remarkably efforts to transcend local values-emotions so as to aspire for ethically more promising and enabling ways of living through catastrophe.

Doctors are no different from laypersons in drawing on personal and cultural resources involving imagination, responsibility, sensibility, and insight and communication to accomplish caregiving. And what they engage is ethical, aesthetic, religious and practical action. The physician's art -- --now so circumcised by bureaucratic and political economic forces -- -- turns on both the professionalization of these inherently human resources and the impact of their routine use on her/his own moral life (as spouse, parent, friend, individual). To prepare for a career of caregiving, medical students and young doctors clearly require something besides scientific and technological training. Indeed, that professional education can even be seen as enabling the physician as a technical expert, whilst disabling her/him as a caregiver. It is for this reason that the incorporation of the humanities in medical training holds promise as a means of rekindling and deepening those human experiences of imagination and commitment essential for caregiving, and resisting the bureaucratization of values and emotional response that conduces to failures in the physician's art.

There are different ways this can be accomplished. Medical schools have taught narratives and their interpretation to sensitize students to the richness of the patient's life world and interests. Historical and cultural analysis has been use to decenter the doctor's experience and provide insight into how suffering and caregiving are distinctively organized in different local moral worlds. The doctor's way of seeing has been challenged by art historians; and ethnomusicologists and musicians have taught doctors new ways to interpret sound and silence; while exposure to other arts has aimed as well at strengthening doctors's access to their own feelings and use of those affects to deepen clinical encounters. Ethicists have unpacked the moral complexity of suffering and encouraged the aspiration for ethical practice. Religionists have inspired physicians not to turn away from patients' questions about ultimate meaning, but to listen and show 
respect for their quest. I am not convinced there is a single best strategy or discipline. Yet, I do believe that what doctors need to be helped to master is the art of acknowledging and affirming the other as a suffering human being; imagining alternative contexts and practices of responding to calamity; and being with, conversing with, and doing for patients in desperate situations where the emphasis is on what really matters to them and their intimates. A program of medical training that makes this happen, however it is innovated, should combine practical experience of caregiving for health catastrophes, in homes and institutions, where students actually do those things that families do, and thereby learn those existentially crucial things families learn, with the knowledge basis that stands behind the art of medicine, and that means interpretive theory and methods from humanists and social scientists. What incentivizes the latter to collaborate with medicine is the opportunity to make interpretive scholarship salient for real world problems. The medical humanities can be envisioned as the biocultural bridge between different domains of the university; it is one of those frail but promising connectors between the world of knowledge creation and the world of practical moral experience. What we now need are conclusions from specific teaching innovations about how useful for improving the quality of doctoring are different medical humanities programs that prepare medical students and young doctors to be caregivers and enable the caregiving of others.

Such programs should be exposed to robust educational evaluation, which heretofore has not been applied. Evaluation should become the basis for scaling up and implementing programs in medical schools, hospitals and continuing medical education. The implementation of useful programs will require parallel attention to the structural and cultural barriers that undermine caregiving in practice settings so as to encourage the experience of caregiving as core to the professional and personal life of the doctor. This will also mean that students and practitioners acquire those interpretive skills of cultural self-reflection that enable them to understand and respond to all those barriers-time, space, culture, etc. - that cause doctors to fail at the art of healing.

Arthur Kleinman

Esther and Sidney Rabb Professor of Anthropology, Harvard University and Professor of Medical Anthropology and Psychiatry, Harvard Medical School 